\title{
PENYULUHAN APLIKASI CISCO WEBEX MEETING SEBAGAI SARANA BELAJAR DARING MATA PELAJARAN KEWIRAUSAHAAN BAGI SISWA SMA
}

\author{
Hanggono Arie Prabowo'), Syamsul Hadi2), Fitriyah Puspita ${ }^{3)}$, Mu'thia Mubasyira4), \\ Agus Abdillah ${ }^{5}$, Subhan Harie ${ }^{6)}$, Nur Rizkiyah ${ }^{7)}$ \\ 1)Program Studi Informatika, ${ }^{2,3,5}$ )Program Studi Pendidikan Ekonomi, ${ }^{4}$ Program \\ Studi Pendidikan Bahasa Inggris, ${ }^{5,6}$ Program Studi Pendidikan Biologi \\ $1,2,3,4,5,6,7)$ Universitas Indraprasta PGRI Jakarta \\ 1)hanggono.arie@gmail.com, ${ }^{2)}$ syamsul.mii@gmail.com, ${ }^{3)}$ fitriyahpuspita23@gmail.com, \\ ${ }^{4)}$ muthia.mubashira@yahoo.com, 5)gusti_cokrodiningrat@yahoo.co.id, \\ ${ }^{6)}$ subhanharie@gmail.com, ${ }^{7}$ qytaman@yahoo.com
}

\section{Histori artikel}

Received:

2 November 2020

Accepted:

29 November 2020

Published:

30 November 2020

\begin{abstract}
Abstrak
Tujuan Kegiatan pengabdian kepada masyarakat ini adalah untuk meningkatkan pengetahuan dan keterampilan pembelajaran daring pada pelajaran kewirausahaan para siswa SMA Bangun Persada Kota Bekasi. Kegiatan diadakan pada bulan Oktober sampai dengan Desember 2019. Kegiatan ini menggunakan tahapan dan metode penyuluhan, pendampingan praktek dan evaluasi serta wawancara. Kegiatan ini diikuti sebanyak 32 siswa kelas X IPS.Hasil kegiatan menunjukkan bahwa siswa sudah dapat mengetahui teori dan aplikasi cisco webex. Mereka dapat memahami materi kewirausahaan yang meliputi materi perencanaan kerajinan dan pemasaran produk. Nilai rata - rata pengantar aplikasi 75, Fungsi dan manfaat Webex 76, dan praktek dan aplikasi webex sebesar 73 .
\end{abstract}

Kata-kata kunci: penyuluhan kewirausahaan, belajar daring, cisco webex meeting 
Abstract. The purpose of this community service activity is to increase knowledge and online learning skills in entrepreneurship lessons for Bangun Persada High School Bekasi City students. Activities were held from October to December 2019. This activity uses stages and methods of counseling, practical assistance and evaluation. This activity was attended by 32 students of class X IPS. The results showed that students were able to know the theory and application of Cisco Webex. They can understand entrepreneurship material which includes craft planning and product marketing materials. The average value of introductory applications is 75 , functions and benefits of Webex is 76 , and practices and applications of Webex are 73.

Keywords: counseling of entrepreneurship, online learning, cisco webex meeting

\section{PENDAHULUAN}

Pembelajaran daring di era industry 4.0 membuat para siswa dan guru menyesuaikan kemajuan yang cepat. bervariatif antar siswa termasuk mempertimbangkan kesenjangan akses belajar dari rumah (Astini, 2020). Penyesuaian itu tidak diimbangi dengan kecepatan kemauan teknologi yang melesat bergerak lebih cepat, ketimbang kemampuan para siswa dan guru. Ketidakseimbangan ini meliputi kemampuan siswa dalam menggunakan program pembelajaran daring dan kemampuan untuk melakukan pelajaran yang bersifat aplikatif, seperti kewirausahaan yang harus dipraktekkan langsung. Dari hasil penelitian terdahulu yang dilakukan oleh Kamayanthy pada tahun 2020, perlu adanya program pembelajaran jarak jauh pada mata pelajaran Kewirusahaan.pembelajaran yang efektif dapat dilaksanakan jika siswa dapat mempraktekkan teori yang mereka kuasai, dan para siswa memerlukan variasi pembelajaran yang menarik, sehingga tidak bosan dan tidak semangat (Widiyarto, Wulansari, dan Hasanusi, 2020). Selain itu, tidak semua peserta didik memiliki handphone berbasis android serta kesenjangan ekonomi menjadi kendala serius membuat para orang tua dan siswa mengalami kesulitan (Mansyur, 2020). Dalam rangka memenuhi kebutuhan jaringan internet. Kemahiran e- learning unuk siswa perlu diperkuat, agar para siswa dapat menyesuaikan kemajuan teknologi yang berkembang cepat dan selalu beradaptasi dengan perkembangan zaman (Astiny, 2020)

Penyesuaian pembelajaran ini memerlukan waktu, dan proses, sehingga dapat menimbulkan permasalah dalam pembelajaran. Khususnya diberbagai sekolah. Sebutkan saja sekolah X yang ada di kota Bekasi. Masih mempunya kendala program pembelajaran mana yang sesuai dan sederhana. Permasalahan yang ditimbulkan akibat pandemic corona sangat terasa bagi para siswa SMA Bangun Pesada. Karena mereka belum terbiasa dan mengenal pembelajaran jarak jauh. Dari wawancara awal tim pengabdian masyarakat, sebagian besar siswa belum pernah menggunakan program daring, pembelajaran kewirausahaan. Mereka hanya mendengar dan belajar secara tatap muka, sebelum virus pandemic meluas hingga saat ini.

Proses E-Learning yang dapat digunakan salah satunya adalah aplikasi dari Cisco Webex Meeting dimana dalam pertemuan daring para siswa mampu bertatap muka secara daring dan dapat menerima materi yang akan diberikan oleh para guru. E-learning merupakan proses perpindahan pendidikan lama ke dalam bentuk digital, secara isi (konten) 
dan sistemnya. Perkembangan teknologi internet sangat mempengaruhi banyak hal, diantaranya adalah lahir konsep e-learning.

Metode pembelajaran e-learning merupakan pembelajaran elektronik menggunakan komputer/handphone android dengan dibantu oleh internet/intranet/jaringan komputer lain sehingga diharapkan mampu menciptakan suasana yang menarik dan menyenangkan dalam proses belajar sehingga dapat membangkitkan semangat belajar peserta didik. Untuk itu para pengabdi masyarakat tertarik untuk membantu para siswa dalam memahami aplikasi, agar mempunyai wawasan pembelajaran daring yang lebih baik. Selanjutnya proses pembelajaran daring meliputi berbagau mata pelajaran, tim memberikan perhatian kepada mata pelajaran kewirausahaan yang perlu mendapat porsi yang cukup, sehingga kelak mereka menjadi wirausahawan yang tangguh.

Cisco Webex Meetings merupakan aplikasi video conference untuk diskusi jarak jauh yang sudah ada sejak tahun 90-an. Meski awalnya dikenal sebagai aplikasi bisnis, Cisco Webex juga banyak digunakan para pelajar hingga pekerja profesional yang bekerja dari rumah. Aplikasi ini dapat digunakan secara gratis dan mampu menampung kapasitas peserta rapat hingga 100 orang tanpa ada batasan waktu. Untuk kebutuhan pembelajaran daring, Cisco Webex dapat memungkinkan tenaga pendidik untuk berbagi konten presentasi melalui papan tulis digital di layar komputer/smartphone. Keunggulan lain yakni ada juga fitur group chat di Cisco Webex Teams dan kelas digital berbasis messaging yang disediakan (https://www.indozone.id)

Cisco adalah peralatan utama yang banyak digunakan pada Wide Area Network (WAN) atau jaringan area luas. Dengan cisco router informasi dapat diteruskan ke alamatalamat yang berjauhan dan berada di jaringan komputer yang lain. Webex merupakan suatu aplikasi daring yang dirancang oleh cisco yang membuat para user name dapat saling berkerjasama lewat gambar, video, dan suara dari mana pun secara lebih mudah. Jadi cisco webex sebagai media pembelajaran interaktif berbasis teknologi informasi yang berfungsi sebagai penyampaian informasi, komunikasi, pendidikan, dan pelatihan secara online. Selain itu cisco webex juga menyediakan seperangkat alat yang dapat memperkaya nilai belajar secara konvensional (Zakaria, 2010). Metode ini adalah metode pengajaran yang mampu menciptakan pembelajaran yang interaktif dan komunikatif. Para siswa dapat berinteraksi dengan guru serta dapat membahas materi secara langsung. Berdasarkan urauian diatas maka tim mengadakan penyuluhan aplikasi cisco webex meeting sebagai sarana belajar daring mata pelajaran kewirausahaan bagi siswa SMA. Namun upaya yang sudah dilaksanakan oleh pemerintah dan pihak swasta sudah banyak. Masih perlu dukungan banyak pihak (Sunarmintyastuti dan Suprapto, 2020). 


\section{METODE PELAKSANAAN}

Peserta penyuluhan SMA Bangun Persada sebanyak 32 siswa, terdiri dari Program studi pemasaran 20 siswa dan program studi akutansi sebanyak 12 siswa. Kegiatan ini dilaksanakan pada bulan Oktober 2019 sampai dengan Desember 2019 Kegiatan diadakan di Jalan Wibawa Mukti 4 Jatimekar Bekasi. Kegiatan ini menggunakan tahapan dan metode penyuluhan, pendampingan, praktek evaluasi serta wawancara. Pada tahap penyuluhan siswa diajar melalui daring, dan tatap muka. Peserta pelatihan diberikan pemahaman konseptual tentang pembelajaran jarak jauh sekaligus mempraktekkan penggunaan instrumen atau aplikasi pembelajaran daring (Ariadhy, 2020) Jika siswa mempunyai permasalahan, para siswa dapat bertanya melalui WA grup yang sudah disediakan oleh tim. Kegiatan penyuluhan meliputi materi dasar program, aplikasi program, dan penggunaan yang tepat dan efektif.

Sedangkan pendampingan meliputi, penggunaan aplikasi secara berkelompok dan didamping oleh penyuluh, termasuk penggunaan WA grup. Pada tahapan praktek dan evaluasi, para siswa diberikan ujian dan tanya jawab, sehingga siswa mampu menggunakan aplikasi dengan benar. Materi kewirausahaan yang diberikan meliputi perencanaan kerajinan tangan dan pemasaran produk. Adapun instrument yang digunakan dalam mengukur keberhasilan siswa meliputi: a. pengantar aplikasi, b. fungsi dan manfaat webex dan c. praktek penggunaan apliksi webex, termasuk dapat terhubung pada platform pembelajaran daring tepat waktu. Untuk pengantar aplikasi dan fungsi, manfaat webex diberikan soal sebanyak 30 nomor, sedangkan untuk praktek penggunaan aplikasi webex, diambil dari ketepatan waktu terhubung platform dan kemampuan menulis tugas dalam bentuk tulisan maupun gambar. Setelah tim memberikan tes, tim mengadakan wawancara kepada beberapa siswa, untuk melihat sejauh mana respon dan manfaat penggunaaan aplikasi daring. Hasil tes dikumpulkan dan diolah, termasuk hasil wawancara.

\section{HASIL DAN PEMBAHASAN}

Kegiatan pengabdian kepada masyarakat ini, terdiri dari beberapa tahapan. Tahapan ini dibagi menjadi tiga sesi, tiap sesi dilakukan sebanyak 90 menit. Tim juga melakukan koordinasi dengan pihak sekolah dan yayasan. Tim membagi tugas, sebagai pemateri, tim pembuat materi, dan tim penanggung jawab konsumsi. Adapun materi yang diberikan sebagai berikut:

Tabel 1. Materi Penyuluhan

\begin{tabular}{clc}
\hline No & \multicolumn{1}{c}{ Materi } & Penyuluh Materi \\
\hline 1 & Pengantar Aplikasi daring & Subhan Harie dan Dini \\
\hline 2 & Fungsi dan Manfaat Cisco Webex & Subhan Harie dan Tim \\
\hline 3 & Praktek aplikasi & Semua anggota tim \\
4 & Evaluasi (teori dan praktek ) & Semua Anggota Tim \\
\hline 5 & Materi kewirausahaan melalui daring & Semua anggota Tim \\
\hline
\end{tabular}


Pada pertemuan awal tim memperkenalkan diri kepada para guru, kepala sekolah, yayasan dan para murid. Pada kesempatan awal tim memberikan sedikit pengenalan materi, sekaligus memberikan jadwal pengabdian kepada masyarakat. Respon para guru, kepala sekolah, yayasan dan para murid cukup baik, hal ini dibuktikan banyaknya pertanyaan dan harapan para guru dan murid agar, pembelajaran dapat dibarengi dengan kemampuan ilmu pengetahuan yang baik.

Selanjutnya pada sesi berikutnya tim melaksanakan penyuluhan dan pendampingan, para siswa diberikan materi. Kegiatan ini dapat berjalan lancar, didukung sarana laboratorium komputer yang telah ada, meski hanya 20 set komputer, namun cukup membantu tim untuk memberikan materi teori dan praktek kepada para siswa. Oleh karena jumlah siswa sebanyak 42 siswa, maka tim membagi 2 kelompok, agar dapat menggunakan komputer secara baik.

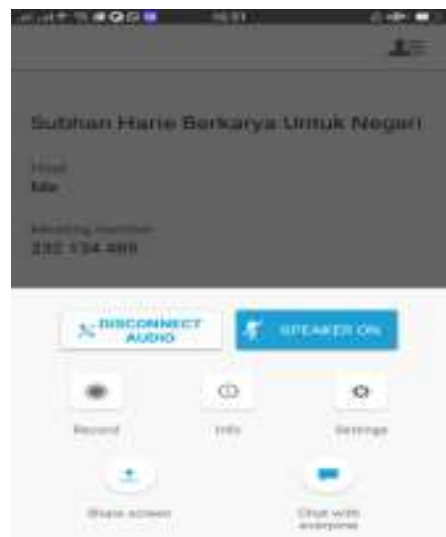

\section{Gambar 1. Proses Operasional Cisco Webex}

Pada saat siswa belajar, dan mempraktekkan langsung aplikasi, para siswa dibimbing dengan cermat, agar mereka dapat memahami dan mengerti setiap proses penggunaan aplikasi. Kegiatan ini berfokus kepada pemberdayaan siswa, agar dapat mandiri dalam hal penggunaaan teknologi dan pembelajaran kewirausahaan (Vernia, 2020). 


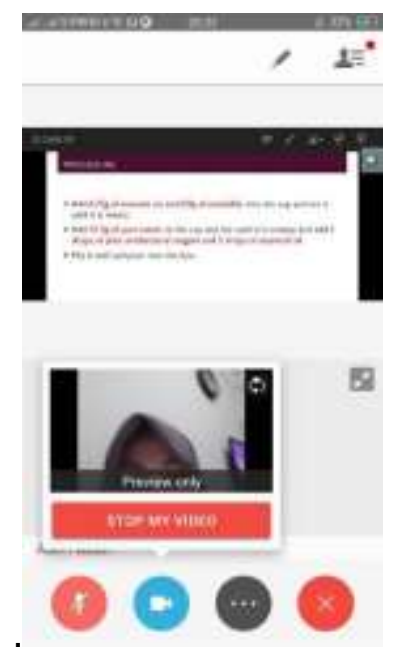

\section{Gambar 2. Proses Pembelajaran Cisco Webex}

Tim memberikan beberapa contoh penggunaan aplikasi, dan mempraktekan didepan para siswa. Pada sesi pertama, kedua dan ketiga para siswa dapat memahami dan mempraktekan langsung aplikasi ini, namun ada beberapa siswa yang mengalami kesulitan, hal tersebut dapat diatasi oleh tim, dengan memberikan contoh berulang kali. Siswa yang mengalami kesulitan pada umumnya kurang melatih dan kurang mempraktekkan apa yang sudah dijelaskan. Hal ini perlu kerjasama semua pihak yang berkepentingan, namun upaya yang sudah dilaksanakan oleh pemerintah dan pihak swasta sudah banyak. masih perlu dukungan banyak pihak, termasuk orang tua murid (Sunarmintyastuti dkk., 2020). Tim memberikan contoh materi kewirusahaan via daring. Adapun materi yang diberikan adalah perencanaan kerajinan tangan dan pemasaran produk

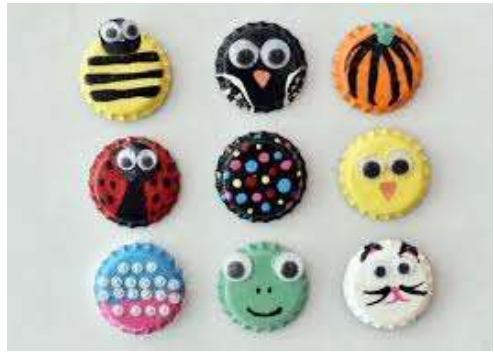

\section{Gambar 3. Hasil Produk Kewirausahaan}

Pada tahapan akhir para siswa dapat merencanakan pembuatan kerajinan, hiasan kulkas dari berbagai gambar "emoticon". Seperti yang ada pada gambar 3. Setelah tim melaksanakan semua jadwal penyuluhan, maka tim memberikan evaluasi, baik teori dan praktek, teori mereka diberikan soal pilihan ganda sebanyak 20 nomor, sedangkan praktek, tim memberikan perintah langsung kepada para siswa bagaimana praktek operasional aplikasi, adapun hasil evaluasi dapat disajikan dalam bentuk bagan sebagai berikut: 


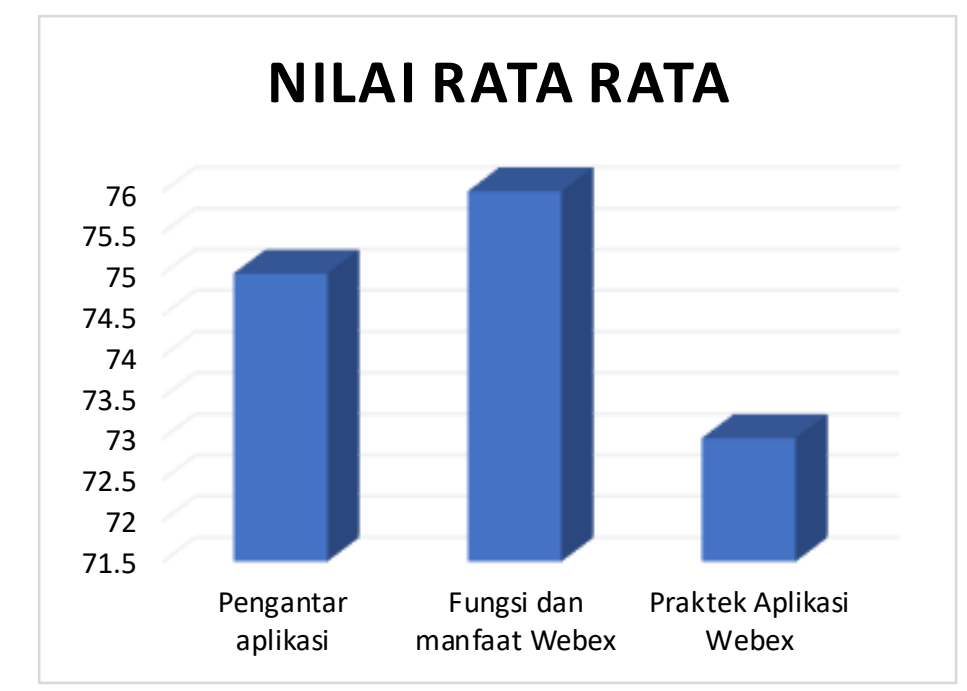

\section{Gambar 4. Grafik Nilai Rata - Rata Peserta Penyuluhan}

\section{KESIMPULAN}

Pembelajaran aplikasi Cisco webex merupakan aplikasi yang bermanfaat dalam pembelajaran jarak jauh. Penggunaan aplikasi ini, dapat dikuasai oleh siswa jika siswa sering menggunakan aplikasi ini, sehingga mereka mahir dan cekatan dalam mempraktekan aplikasi ini. Para siswa cukup menguasai aplikasi ini, baik teori dan praktek, hanya saja perlu pengembangan dan latihan yang lebih intensif, agar penggunaan aplikasi tidak mudah lupa. Materi kewirausahaan sangat penting untuk diaplikasikan melalui daring, produk yang dihasilkan dapat dibuat sekaligus dipasarkan melalui daring. Kegiatan penyuluhan aplikasi cisco webex meeting sebagai sarana belajar daring mata pelajaran kewirausahaan bagi siswa SMA, dapat membantu proses belajar mengajar di SMA Bangun Pesada. Para siswa mendapat pengalaman baru. Mereka dapat menggunakan aplikasi, sekaligus menghsilkan produk dalam pembelajaran kewirausahaan. Selain teori dan aplikasi program, mereka antusias dalam mengikuti pembelajaran melalui daring. Para siswa sangat responsif dalam menerima penyuluhan ini, dari hasil wawancara para siswa berpendapat, dengan diadakan penyuluhan ini, mereka dapat mengenal dan menguasai aplikasi ini. Dari hasil evaluasi mereka mempunyai nilai rata-rata 74,6 (gabungan rata-rata dari pengantar aplikasi, fungsi dan praktek aplikasi Webex)

\section{DAFTAR PUSTAKA}

Ariadhy, S. Y., Nurohman, S., Arkum, D., Handini, W., \& Ferdiana, F. (2020). Pelatihan pembelajaran jarak jauh di era pandemi covid-19. Jurnal Anoa, 1(3), 220-226.

Astini, N. K. S. (2020). Pemanfaatan teknologi informasi dalam pembelajaran tingkat sekolah dasar pada masa pandemi covid-19. Lampuhyang, 11(2), 13-25.

Ati, A. P., Cleopatra, M., \& Widiyarto, S. (2020). Strategi pembelajaran dan pengajaran menulis bahasa indonesia: tantangan di era revolusi industri 4.0. Prosiding. Samasta. 
Bawden, D. (2008). Origins and concepts of digital literacy, in: Digital Literacies: Concepts, Policies and Practices, Peter Lang Publishing, New York

Hadi, S., Puspita, F., Ati, A. P., \& Widiyarto, S. (2020). Penyuluhan dan pembelajaran karakter melalui pelaksanaan idul adha pada siswa SMA. Jurnal Pemberdayaan: Publikasi Hasil Pengabdian kepada Masyarakat, 4(2), 205-210.

Kamayanthy, D. Y. (2020). Analisis pembelajaran menggunakan edmodo pada mata pelajaran kewirausahaan kelas XII DPIB di SMKN 1 majalengka tahun ajaran 20202021. Disertasi. FKIP Unpas

Mansyur, A. R. (2020). Dampak covid-19 terhadap dinamika pembelajaran di indonesia. Education and Learning Journal, 1(2), 113-123.

Sunarmintyastuti, L., \& Suprapto, H. A. (2020). Pengembangan SDM melalui minat dan motivasi santriwati pada yayasan Taufidzul Qur'an Ar-rahmani di Ciputat Tangerang Selatan. Jurnal IImiah Wahana Pendidikan, 6(2), 104-109.

Sunarmintyastuti, L., Suprapto, H. A., Sandiar, L., Leksono, A. W., \& Widiyarto, S. (2020). Penyuluhan kewirausahaan dan pemberdayaan siswa yatim piatu di ciputat tangerang selatan banten. Abidumasy Jurnal Pengabdian Kepada Masyarakat, 1(2), 24-29.

Supandi, A., Sahrazad, S., Wibowo, A. N.,\& Widiyarto, S. (2020). Analisis Kompetensi Guru: Pembelajaran Revolusi Industri 4.0. Prosiding. Samasta.

Suprapto, H. A. (2018). Pelatihan pembuatan proposal rencana bisnis (business plan) bagi siswa madrasah Tsanawiyah Nurul Hikmah dan SMP Al-ihsan guna meningkatkan kemampuan berwirausaha. Abdimas Siliwangi, 1(2), 81-88.

Vernia, D. M., Widiyarto, S., Narsih, D., \& Tiwinyanti, L. (2020). Sosialisasi dan pembekalan strategi pemasaran produk olahan pisang pada siswa pondok. Jurnal Pengabdian UntukMu NegeRI, 4(1), 125-128.

Vernia, D. M., Widiyarto, S., Wulansari, L., \& Rusdi, M. (2018). penyuluhan dalam meningkatkan partisipasi program dana desa. Prosiding Sembadha, 1(1), 72-78.

Widiyarto, S., Narsih, D., Ati, A. P., Vernia, D. M., \& Alifah, S. (2020). Pelatihan pajak pph 21 dalam rangka membangun kesadaran pajak pada siswa SMK Bangun Persada Bekasi. Intervensi Komunitas, 2(1)

Widiyarto, S., Wulansari, L., \& Hasanusi, F. S. (2020). Pelatihan "english communicative" guna mempersiapkan sdm berkualitas dan "competitive". Intervensi Komunitas, 1(2), 125-131.

Zakaria, Y. (2010). Peningkatan proses belajar siswa melalui model pembelajaran sea digital class menggunakan edmodo dan webex studi kasus: SMK Informatika Al-Irsyad. Skripsi. Sekolah Tinggi Informasi dan Manajemen Cirebon 